\title{
Treatment of Nitrogen Heterocyclic Compounds (NHCs) in Coking Wastewater by White-Rot Fungi
}

\section{Tratamiento de compuestos heterocíclicos de nitrógeno (NHC) en aguas residuales de coque por hongos de pudrición blanca}
C. Huang ${ }^{1}$
D. $\operatorname{Ren}^{2} *$
C. $\mathrm{Kang}^{3}$
Z. Deng ${ }^{4}$
H. Guo ${ }^{5}$
S. Zhang ${ }^{6}$
X. Zhang ${ }^{7}$

${ }^{1}$ College of Resource and Environmental Engineering, Wuhan University of Science and Technology, Wuhan, China

Hubei Key Laboratory for Efficient Utilization and Agglomeration of metallurgic Mineral Resources, Wuhan University of Science and Technology, Wuhan, China, email: 740491866@qq.com, ORCID 0000-0003-1077-9444

${ }^{2}$ College of Resource and Environmental Engineering, Wuhan University of Science and Technology, Wuhan, China

Hubei Key Laboratory for Efficient Utilization and Agglomeration of metallurgic Mineral Resources, Wuhan University of Science and Technology, Wuhan, China, email: dj_ren@163.com, ORCID 0000-0003-0752-4184

${ }^{3}$ College of Resource and Environmental Engineering, Wuhan University of Science and Technology, Wuhan, China

Hubei Key Laboratory for Efficient Utilization and Agglomeration of metallurgic Mineral Resources, Wuhan University of Science and Technology, Wuhan, China, email: 914010147@qq.com, ORCID 0000-0002-0972-3286

${ }^{4}$ College of Resource and Environmental Engineering, Wuhan University of Science and Technology, Wuhan, China 
Hubei Key Laboratory for Efficient Utilization and Agglomeration of metallurgic Mineral Resources, Wuhan University of Science and Technology, Wuhan, China, email: 1163909723@qq.com, ORCID 0000-0002-5459-1374

${ }^{5}$ College of Resource and Environmental Engineering, Wuhan University of Science and Technology, Wuhan, China

Hubei Key Laboratory for Efficient Utilization and Agglomeration of metallurgic Mineral Resources, Wuhan University of Science and Technology, Wuhan, China, email: 545645621@qq.com, ORCID 0000-0001-7481-8380

${ }^{6}$ College of Resource and Environmental Engineering, Wuhan University of Science and Technology, Wuhan, China

Hubei Key Laboratory for Efficient Utilization and Agglomeration of metallurgic Mineral Resources, Wuhan University of Science and Technology, Wuhan, China, email: zhangshuqin@wust.edu.com, ORCID 0000-0002-1572-308X

${ }^{7}$ College of Resource and Environmental Engineering, Wuhan University of Science and Technology, Wuhan, China

Hubei Key Laboratory for Efficient Utilization and Agglomeration of metallurgic Mineral Resources, Wuhan University of Science and Technology, Wuhan, China, email: zhangxiaoqing@wust.edu.com, ORCID 0000-0002-6456-0600

*Corresponding author: Dajun Ren, dj_ren@163.com

\section{Abstract}

In the present study the white-rot fungi BP was selected to study the degradation of nitrogen heterocyclic compounds in real and simulated coking wastewater. The study incorporated analysis of the degradation process, mechanism of action of white-rot fungi on nitrogen heterocyclic compounds, changes of enzyme activity and white-rot fungi biomass growth rate in coking wastewater (simulated and actual). The results showed that the addition of ammonia nitrogen and phenol in simulated wastewater had insignificant effects on the degradation of indole. Moreover, the promoting effect of phenol on quinoline degradation was greater than the inhibition effects of ammonia nitrogen. Degradation rates of quinoline, indole and pyridine are consistent with the zero-order kinetics equation. It was also found that the addition of $\mathrm{Mg}$ (II) and $\mathrm{Mn}$ (II) promotes the degradation of quinoline by white-rot fungi in the actual wastewater, while degradation of pyridine was inhibited by three ions, out of which the inhibition of $\mathrm{Cu}$ 
(II) was the most obvious. Cu (II) was also found to have positive effects on the levels of activity of laccase enzyme secreted by the white-rot fungi as opposed to other metal ions tested. However, it was found to have inhibitory effects on the development of white-rot fungi, while $\mathrm{Mg}$ (II) and Mn (II) were found to promote the development of the white-rot fungi. The activity of the enzyme and the growth rate of the biomass of white-rot fungi first reached the maximum levels followed by a significant decline.

Keywords: White-rot fungi, Coking wastewater, Nitrogen heterocyclic compounds, Co-substrate, Laccase.

Received

Accepted

\section{Introduction}

Coking wastewater is the wastewater produced in the process of recovery of coal coking product. It is usually known to contain nitrogen heterocyclic compounds (NHCs) and polycyclic aromatic hydrocarbons (PAHs) that are difficult to biodegrade. It also contains a variety of other toxic substances that act as inhibitors of microbial activity. Therefore, the traditional biochemical treatment technology is difficult to meet the national emission standards for the removal effect of biological nitrogen is not obvious. NHCs account for $20-30 \%$ of the total organic components and are the main component of organic pollutants in coking wastewater (Joshi et al., 2016). The substitution of $\mathrm{N}$ and $\mathrm{S}$ makes these heterocyclic organic compounds more toxic than the corresponding non-heterocyclic organic compounds (Eisentraeger et al., 2008). It is, therefore, crucial to study the biodegradation of nitrogen heterocyclic compounds in coking wastewater in the coexistence of various other organic and inorganic pollutants.

In coking wastewater, quinoline $(Q)$, indole $(I)$, pyridine $(P d)$, phenol $(P)$ and ammonia nitrogen $(\mathrm{N})$ constitute a co-substrate system. Addition of a contaminant in the co-substrate system can either promote or inhibit the degradation of another one (Rasool et al., 2015; Martinez et al., 2015; Wen et al., 2011). Phomopsis liquidambari, Brevundimonas $s p$. and Shinella zoogloeoides have been identified to possess strong specificity for degrading indole, quinoline and pyridine, but not towards coking wastewater with a complex composition (Chen et al., 2013; 
Wang et al., 2015; Bai et al., 2009). On the other hand, many studies have shown that white-rot fungi have a non-specific nature towards the degradation of the substrate and direct or indirect degradation ability for most aromatic compounds. Furthermore, white-rot fungi were also found to degrade a large number of single or mixed matrix contaminants (Pointing et al., 2001). The ability of degradation of multiple single substrate pollutants by white-rot fungi had also been demonstrated in some recently conducted studies (Ren et al., 2012; Stella et al., 2016). On the basis of these revelations, the degradation behavior and kinetic characteristics of four co-substrate systems in simulated coking wastewater were studied in this paper. Further study of the feasibility of degradation of nitrogenous heterocyclic compounds by white-rot fungi in the effect of metal ions in actual coking wastewater was also studied.

\section{Materials and Methods}

\section{Reagent}

Pyridine, quinoline and indole ( $A R$, Sinopharm Group Chemical Reagent Co., Ltd., China); 2,2'-nitro-bis (3-ethylbenzothiazole-6-sulfonic acid) (ABTS) (Sigma-Aldrich); glacial acetic acid: AR; methanol: chromatographic pure; ammonium tartrate; glucose; ammonium sulfate $\left(\left(\mathrm{NH}_{4}\right)_{2} \mathrm{SO}_{4}\right)$; monopotassium phosphate $\left(\mathrm{KH}_{2} \mathrm{PO}_{4}\right)$; magnesium sulfate heptahydrate $\left(\mathrm{MgSO}_{4} \cdot 7 \mathrm{H}_{2} \mathrm{O}\right) ;$ manganese(II) sulfate monohydrate $\left(\mathrm{MnSO}_{4} \cdot \mathrm{H}_{2} \mathrm{O}\right) ;$ copper(II) sulfate pentahydrate $\left(\mathrm{CuSO}_{4} \cdot 5 \mathrm{H}_{2} \mathrm{O}\right)$ and microporous membrane $(0.45 \mu \mathrm{m})$.

\section{Culture of White-Rot Fungi and Preparation of Medium}

White-rot fungal strain (Pleurotus sp.) No. BP, selected and preserved by the Environmental Resources Microbiology Research Laboratory of Huazhong University of Science and Technology, China, was expanded 
after 4 days as a spare bacterial fluid. The medium used in the experiment was a straw filtrate culture medium, consisting of water $(1000 \mathrm{~mL})$, corn stalk powder $(30 \mathrm{~g})$, bran $(8 \mathrm{~g})$ and cottonseed meal $(1.2 \mathrm{~g})$.

\section{Preparation and Testing of Simulated and Actual Wastewater}

$10 \mathrm{~mL}$ bacterial fluid was inoculated into a $250 \mathrm{~mL}$ triangle flask containing $100 \mathrm{~mL}$ culture medium. A Pd+Q+I co-substrate degradation system was made up by adding certain amounts of pyridine $(80 \mathrm{mg} / \mathrm{L})$, quinoline $(80 \mathrm{mg} / \mathrm{L})$ and indole $(80 \mathrm{mg} / \mathrm{L})$ reserve solutions to the culture flask. The solution thus prepared was then added with phenol $(150 \mathrm{mg} / \mathrm{L})$ or ammonia nitrogen (290 mg/L) reserve solutions to simulate the presence of actual coking wastewater. The Erlenmeyer flask, which was inoculated with the bacteria and the substrate, was placed in a shaker (150 r/min) and subjected to a degradation test at $25^{\circ} \mathrm{C}$.

The subsequent experimental setups that were carried on actual coking wastewater culture system contained $50 \mathrm{~mL}$ actual wastewater obtained from Wuhan Iron and Steel Company coking plant (Table 1), and $50 \mathrm{~mL}$ of straw filtrate culture medium, which included four degradation systems: no metal system, Mg (II) system, Cu (II) system, Mn (II) system. The concentration of the metal ions in the culture medium was kept $1.0 \mathrm{mM} / \mathrm{L}$ and the experimental method followed was similar to that of simulated wastewater based experiment.

Table 1. Water quality of coking raw water in coking company.

\begin{tabular}{|c|c|c|c|c|c|c|}
\hline Index & $\begin{array}{c}\text { COD } \\
(\mathrm{mg} / \mathrm{L})\end{array}$ & $\begin{array}{c}\text { Phenols } \\
(\mathrm{mg} / \mathrm{L})\end{array}$ & $\begin{array}{c}\text { Ammonia } \\
\text { nitrogen } \\
(\mathrm{mg} / \mathrm{L})\end{array}$ & $\begin{array}{c}\text { Cyanid } \\
\mathrm{e} \\
(\mathrm{mg} / \mathrm{L})\end{array}$ & $\begin{array}{c}\text { Oils } \\
(\mathrm{mg} / \mathrm{g})\end{array}$ & $\mathrm{pH}$ \\
\hline Concentration & $\leq 3000$ & $\leq 800$ & $\leq 500$ & $\leq 20$ & $\leq 100$ & $6.5-7.5$ \\
\hline
\end{tabular}

\section{Determination}


The concentration of quinoline, indole, pyridine and phenol were measured by using Hitachi HPLC (High Performance Liquid Chromatography) (Hitachi pump (L-7100), Hitachi dynamic mixers, UV-vis L-7420 detector and the Hypersil C-18 reverse column $(250 \mathrm{~mm} \times 4.6 \mathrm{mmI} . \mathrm{D} ., 5 \mu \mathrm{m}))$. The standard curve of characteristic absorption peaks of organic compounds was used for conclusion could be got. The conditions for the determination of indole and phenol were as follows: the mobile phase was methanol and water ( $1 \% \mathrm{HAc})$, the volume ratio was $80: 20$, the flow rate was $0.6 \mathrm{~mL} / \mathrm{min}$, the detection wavelength was $270 \mathrm{~nm}$, and the injection volume was $20 \mu \mathrm{L}$. The conditions for the determination of quinoline were as follows: the mobile phase was methanol and water ( $1 \% \mathrm{HAc})$, the volume ratio was 50:50, the flow rate was $0.6 \mathrm{~mL} / \mathrm{min}$, the detection wavelength was 313 $\mathrm{nm}$, and the injection volume was $20 \mu \mathrm{L}$; and the conditions for the determination of pyridine were as follows: the mobile phase was methanol and water ( $1 \% \mathrm{HAc})$, the volume ratio is $70: 30$, the flow rate was $0.4 \mathrm{~mL} / \mathrm{min}$, the detection wavelength was $254 \mathrm{~nm}$, and the injection volume was $20 \mu \mathrm{L}$.

The biomass dry weight of white-rot fungi was measured with the help of an electronic balance (FA2004). Ammonia nitrogen was analyzed by WT-1 portable ammonia nitrogen analyzer. The laccase activity levels were estimated using a UV-2550 UV spectrophotometer (SHIMADZU CORPORATION, Japan) by the method of Robert. One enzyme activity unit (U) was defined as the absorbance values of per $\mathrm{mL}$ degradable solution per minute increased by 0.001 (Bourbonnais et al., 1992).

\section{Degradation of Simulated Coking Wastewater by White-Rot Fungi}

Based on the $\mathrm{Pd}+\mathrm{Q}+\mathrm{I}$ co-substrate degradation system, ammonia nitrogen or phenol was added to the degradation system to form $\mathrm{Pd}+\mathrm{Q}+\mathrm{I}, \mathrm{N}+\mathrm{Pd}+\mathrm{Q}+\mathrm{I}, \mathrm{P}+\mathrm{Pd}+\mathrm{Q}+\mathrm{I}$ and $\mathrm{N}+\mathrm{P}+\mathrm{Pd}+\mathrm{Q}+\mathrm{I}$. This was done to simulate coking wastewater for the purpose of analysis of the degradation behavior of white-rot fungi on various nitrogen heterocyclic compounds, ammonia and phenol.

\section{Removal Effect and Reaction Kinetics}


The degradation of quinoline by white-rot fungi in four co-substrate degradation systems is shown in Figure 1. After 15 days, the removal rates of quinoline in the four systems of $\mathrm{Pd}+\mathrm{Q}+\mathrm{I}, \mathrm{N}+\mathrm{Pd}+\mathrm{Q}+\mathrm{I}$, $\mathrm{P}+\mathrm{Pd}+\mathrm{Q}+\mathrm{I}$ and $\mathrm{N}+\mathrm{P}+\mathrm{Pd}+\mathrm{Q}+\mathrm{I}$ were $, 66.2 \%, 62.5 \%, 70.0 \%$ and $68.7 \%$, respectively. It is evident that the degradation rate of quinoline in the four systems was almost consistent.

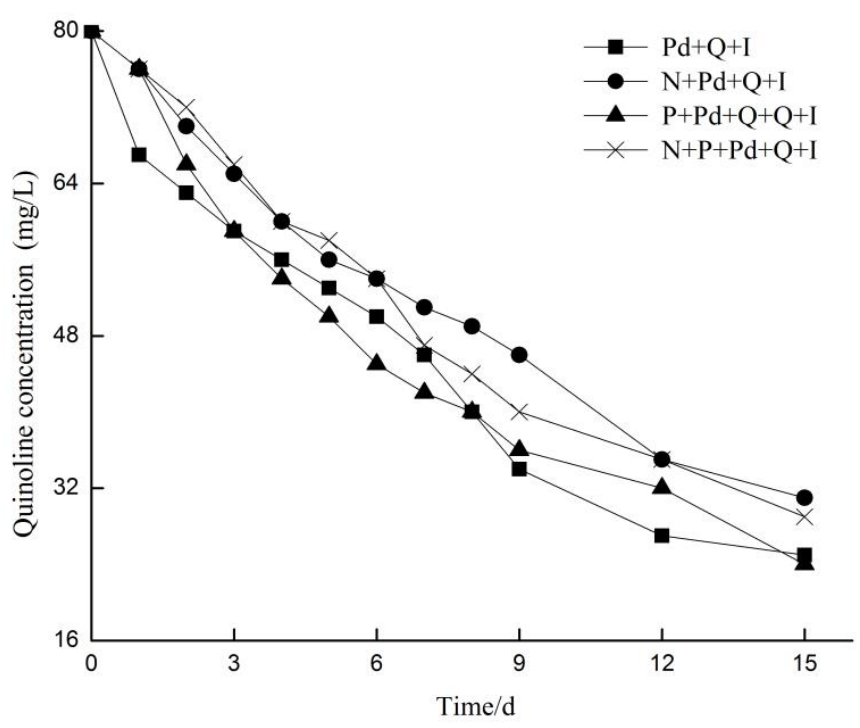

Figure 1. Time dependent changes in quinoline of the four systems.

The degradation data of quinoline in four different co-substrate degradation systems were linearly fitted in the zero-order kinetics equation (Table 2). From Table 2, it can be seen that the quinoline degradation rate constant $\left(k_{0}\right)$ value in the four systems was about 3.5 $\mathrm{mg} / \mathrm{L} \cdot \mathrm{d}$, but with minor variations. Compared with $\mathrm{Pd}+\mathrm{Q}+\mathrm{I}$, the value of $k_{0}$ of $\mathrm{P}+\mathrm{Pd}+\mathrm{Q}+\mathrm{I}$ and $\mathrm{N}+\mathrm{P}+\mathrm{Pd}+\mathrm{Q}+\mathrm{I}$ was slightly increased, while for $\mathrm{N}+\mathrm{Pd}+\mathrm{Q}+\mathrm{I}$ it was slightly decreased.

Table 2. Kinetic equations and parameters of quinoline degradation in different systems.

\begin{tabular}{|c|c|c|c|}
\hline $\begin{array}{c}\text { Co-substrate } \\
\text { system }\end{array}$ & Kinetic equation & $k_{0}(\mathrm{mg} / \mathrm{L} \cdot \mathrm{d})$ & $r^{2}$ \\
\hline $\mathrm{Pd}+\mathrm{Q}+\mathrm{I}$ & $\mathrm{C}=-3.5901 t+71.541$ & 3.5901 & 0.9443 \\
\hline
\end{tabular}




\begin{tabular}{|c|c|c|c|}
\hline $\mathrm{N}+\mathrm{Pd}+\mathrm{Q}+\mathrm{I}$ & $C=-3.3243 t+75.279$ & 3.3243 & 0.9687 \\
\hline $\mathrm{P}+\mathrm{Pd}+\mathrm{Q}+\mathrm{I}$ & $C=-3.7027 t+72.633$ & 3.7027 & 0.9294 \\
\hline $\mathrm{N}+\mathrm{P}+\mathrm{Pd}+\mathrm{Q}+\mathrm{I}$ & $C=-3.6712 t+77.110$ & 3.6712 & 0.9705 \\
\hline
\end{tabular}

The degradation of indole by white-rot fungi in four co-substrate degradation systems is also shown in Figure 2. The fungi could remove more than $99 \%$ of indole by the end of 3 days, and it was also found that the process of indole degradation rate was also consistent, with slight modifications.

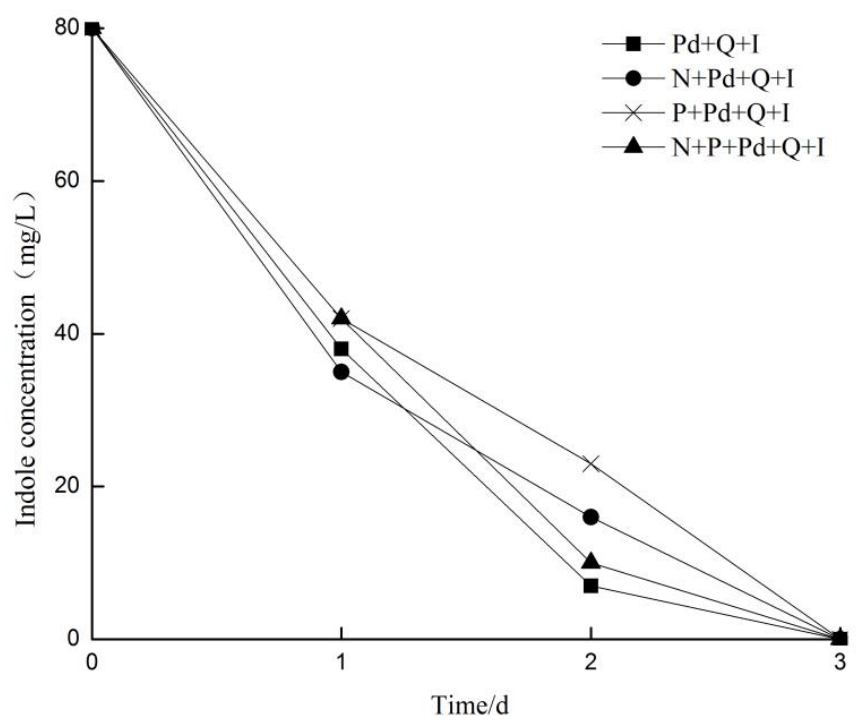

Figure 2. Time dependent changes in indole of the four systems.

The degradation data of indole in four different co-substrate degradation systems was found to fit in the zero-order kinetics equation. Table 3 clearly indicates that the average indole degradation rate constant $\left(k_{1}\right)$ was about 26.5. Compared with $\mathrm{Pd}+\mathrm{Q}+\mathrm{I}$, the degradation rate constants of the other three co-substrate degradation systems decreased slightly, but not obvious.

Table 3. Kinetic equations and parameters of indole degradation in different systems

\begin{tabular}{|c|c|c|c|}
\hline $\begin{array}{c}\text { Co-substrate } \\
\text { system }\end{array}$ & Kinetic equation & $k_{1}(\mathrm{mg} / \mathrm{L} \cdot \mathrm{d})$ & $r^{2}$ \\
\hline $\mathrm{Pd}+\mathrm{Q}+\mathrm{I}$ & $\mathrm{C}=-27.1 t+71.9$ & 27.1 & 0.9211 \\
\hline
\end{tabular}




\begin{tabular}{|c|l|l|l|}
\hline $\mathrm{N}+\mathrm{Pd}+\mathrm{Q}+\mathrm{I}$ & $C=-26.2 t+71.8$ & 26.2 & 0.9360 \\
\hline $\mathrm{P}+\mathrm{Pd}+\mathrm{Q}+\mathrm{I}$ & $C=-26.0 t+75.0$ & 26.0 & 0.9758 \\
\hline $\mathrm{N}+\mathrm{P}+\mathrm{Pd}+\mathrm{Q}+\mathrm{I}$ & $C=-27.0 t+73.5$ & 27.0 & 0.9477 \\
\hline
\end{tabular}

The degradation of pyridine by white-rot fungi in four co-substrate degradation systems are shown in Figure 3. After 15 days, the removal rates of pyridine in the four systems of $\mathrm{Pd}+\mathrm{Q}+\mathrm{I}, \mathrm{N}+\mathrm{Pd}+\mathrm{Q}+\mathrm{I}$, $\mathrm{P}+\mathrm{Pd}+\mathrm{Q}+\mathrm{I}$ and $\mathrm{N}+\mathrm{P}+\mathrm{Pd}+\mathrm{Q}+\mathrm{I}$ were $20 \%, 27 \%, 27.5 \%, 32.5 \%$, respectively. It was found that the degradation rates of pyridine in the four degradation systems were affected by the co-substrate.

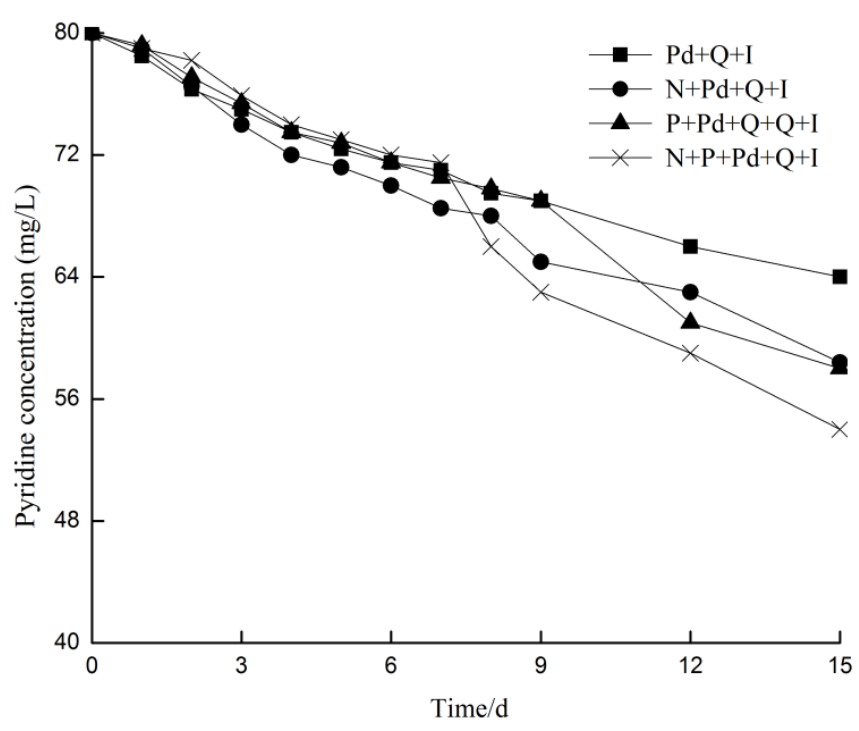

Figure 3. Time dependent changes in pyridine of the four systems.

The degradation data of pyridine in the degradation systems was also found to linearly fit in the zero-order kinetics equation. The data presented in table 4 shows that the pyridine degradation rate constant $\left(k_{2}\right)$ was 1.05 in $\mathrm{P}+\mathrm{Q}+\mathrm{I}$ system. Compared with $\mathrm{Pd}+\mathrm{Q}+\mathrm{I}$, the degradation rate constants were found to increase in the other three co-substrate degradation systems and the $\mathrm{N}+\mathrm{P}+\mathrm{Pd}+\mathrm{Q}+\mathrm{I}$ system was the most obvious.

Table 4. Kinetic equations and parameters of pyridine degradation in different systems.

\begin{tabular}{|c|c|c|c|}
\hline Co-substrate & Kinetic equation & $k_{2}$ & $r^{2}$ \\
\hline
\end{tabular}




\begin{tabular}{|c|c|c|c|}
\hline system & & $(\mathrm{mg} / \mathrm{L} \cdot \mathrm{d})$ & \\
\hline $\mathrm{Pd}+\mathrm{Q}+\mathrm{I}$ & $\mathrm{C}=-1.0500 \mathrm{t}+78.525$ & 1.0500 & 0.9611 \\
\hline $\mathrm{N}+\mathrm{Pd}+\mathrm{Q}+\mathrm{I}$ & $\mathrm{C}=-1.4194 \mathrm{t}+78.983$ & 1.4194 & 0.9789 \\
\hline $\mathrm{P}+\mathrm{Pd}+\mathrm{Q}+\mathrm{I}$ & $\mathrm{C}=-1.4653 \mathrm{t}+80.275$ & 1.4653 & 0.9599 \\
\hline $\mathrm{N}+\mathrm{P}+\mathrm{Pd}+\mathrm{Q}+\mathrm{I}$ & $\mathrm{C}=-1.8198 \mathrm{t}+81.386$ & 1.8198 & 0.9755 \\
\hline
\end{tabular}

\section{Effect of Co-Substrate on Pd+Q+I System}

It could be seen from Figure 4 that the concentration curve of ammonia nitrogen and quinoline were basically the same in the first 3 days of the $\mathrm{N}+\mathrm{Pd}+\mathrm{Q}+\mathrm{I}$ system. After 3 days, the indole concentration decreased to zero and the ammonia concentration began to rise. In Figure 5, it is shown that phenol and indole are the carbon sources that can be directly used by the white-rot fungi in the P+Pd+Q+I system. Hence, on the $3^{\text {rd }}$ and $4^{\text {th }}$ day, white-rot fungi removed more than $99 \%$ indole and phenol. Figure 6 further illustrates that indole and phenol in the $\mathrm{N}+\mathrm{P}+\mathrm{Pd}+\mathrm{Q}+\mathrm{I}$ system were completely removed by the fungi on 3rd and 5 th day. The concentration of ammonia nitrogen was also found to be the lowest in these two days, $241 \mathrm{mg} / \mathrm{L}$ and $246 \mathrm{mg} / \mathrm{L}$, respectively. From these three figures, it is clear that the effect of indole degradation was not obvious when ammonia nitrogen or phenol was used as a co-substrate. In addition, ammonia nitrogen was found to have inhibitory effects on quinoline degradation, but the promoting effects of phenol on quinoline degradation were greater than the inhibition effects of ammonia nitrogen. 


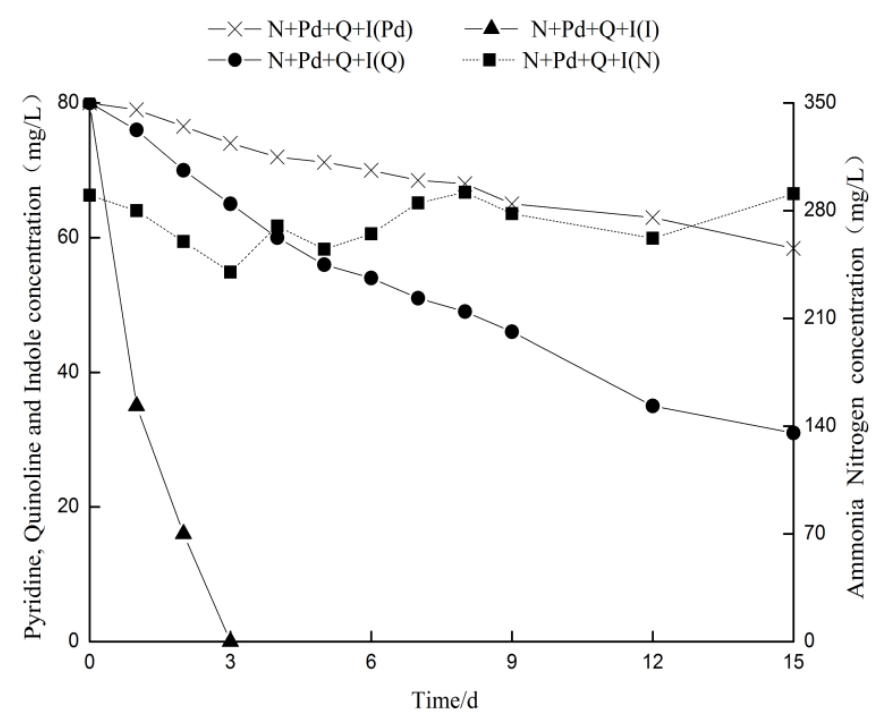

Figure 4. Concentrations of various substances in $\mathrm{N}+\mathrm{Pd}+\mathrm{Q}+\mathrm{I}$ system.

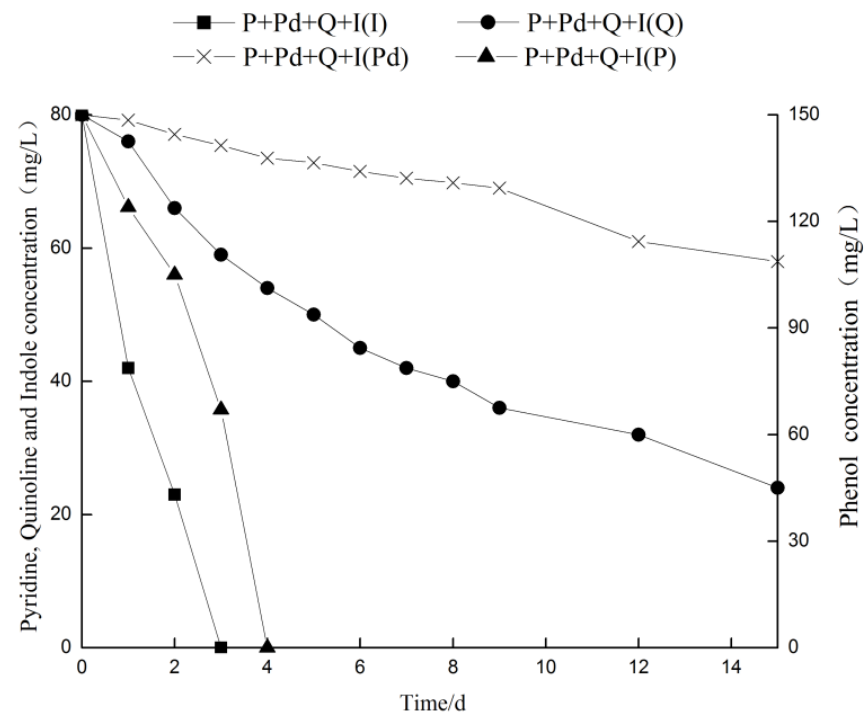

Figure 5. Concentrations of various substances in $P+P d+Q+I$ system. 


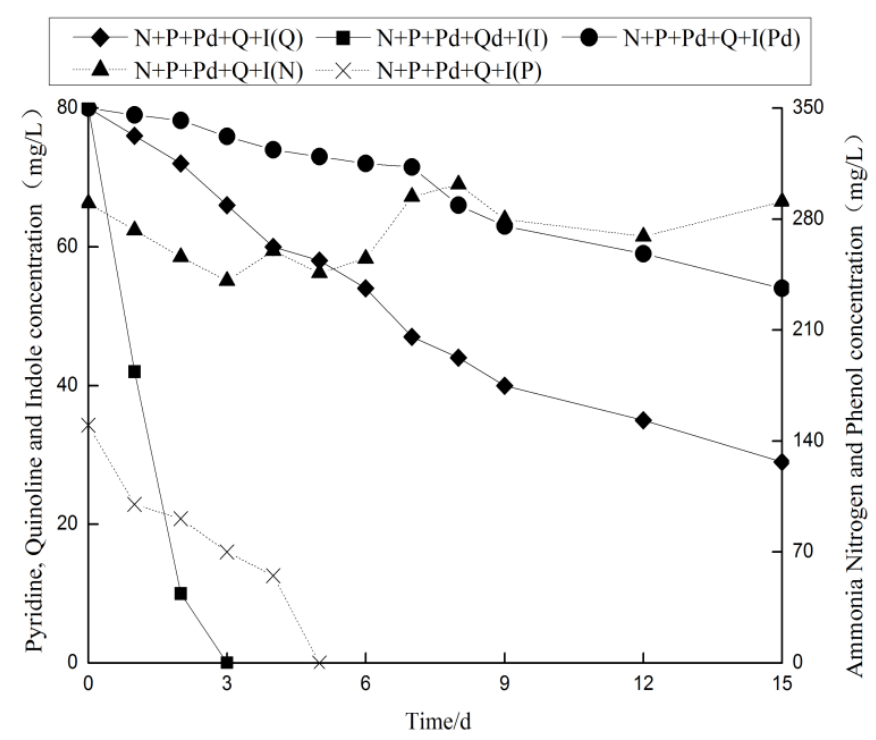

Figure 6. Concentrations of various substances in $N+P+P d+Q+I$ system.

\section{Changes in Enzyme Activity, White-Rot Fungi Biomass and $\mathbf{p H}$}

As illustrated in Figure 7 , on the $3^{\text {rd }}$ day, the laccase activities of white-rot fungi in $\mathrm{Pd}+\mathrm{Q}+\mathrm{I}, \mathrm{N}+\mathrm{Pd}+\mathrm{Q}+\mathrm{I}, \mathrm{P}+\mathrm{Pd}+\mathrm{Q}+\mathrm{I}$ and $\mathrm{N}+\mathrm{P}+\mathrm{Pd}+\mathrm{Q}+\mathrm{I}$ reached the maximum levels of $366,485,401$ and $411 \mathrm{U} / \mathrm{mL}$, respectively. Compared with $\mathrm{Pd}+\mathrm{Q}+\mathrm{I}$, the other three systems had even higher laccase activity peaks. 


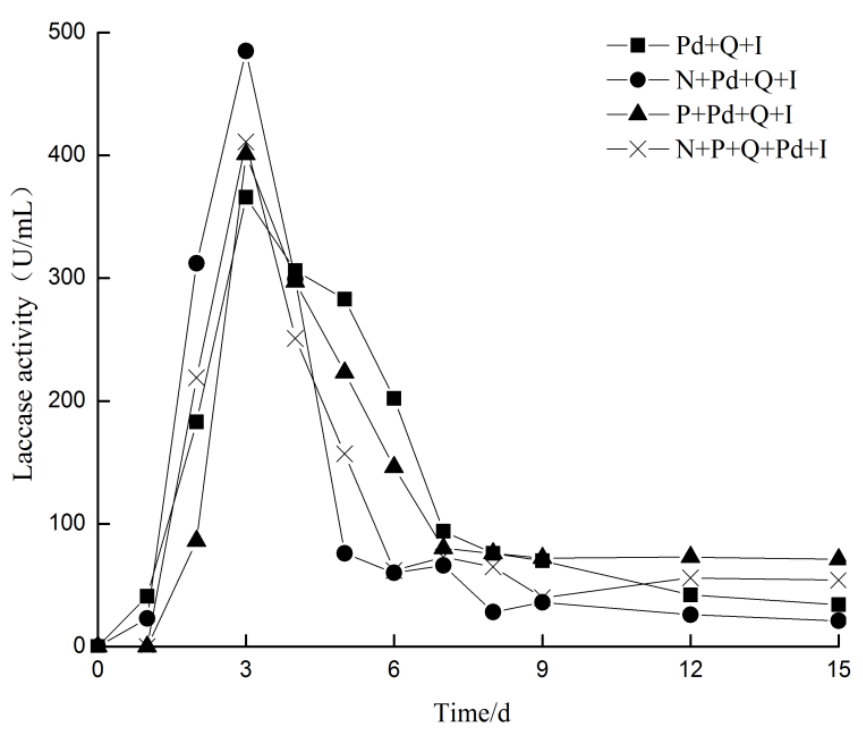

Figure 7. Changes of laccase activities of white-rot fungi.

As illustrated in Figure 8, the growth rates of the fungi in the $P d+Q+I$, $\mathrm{N}+\mathrm{Pd}+\mathrm{Q}+\mathrm{I}, \mathrm{P}+\mathrm{Pd}+\mathrm{Q}+\mathrm{I}$ and $\mathrm{N}+\mathrm{P}+\mathrm{Pd}+\mathrm{Q}+\mathrm{I}$ conditions reached the maximum values of $0.106,0.102,0.100$ and $0.085 \mathrm{~g} / \mathrm{d}$ on the $2^{\text {nd }}, 2^{\text {nd }}$, $3^{\text {rd }}$ and $2^{\text {nd }}$ days, respectively.

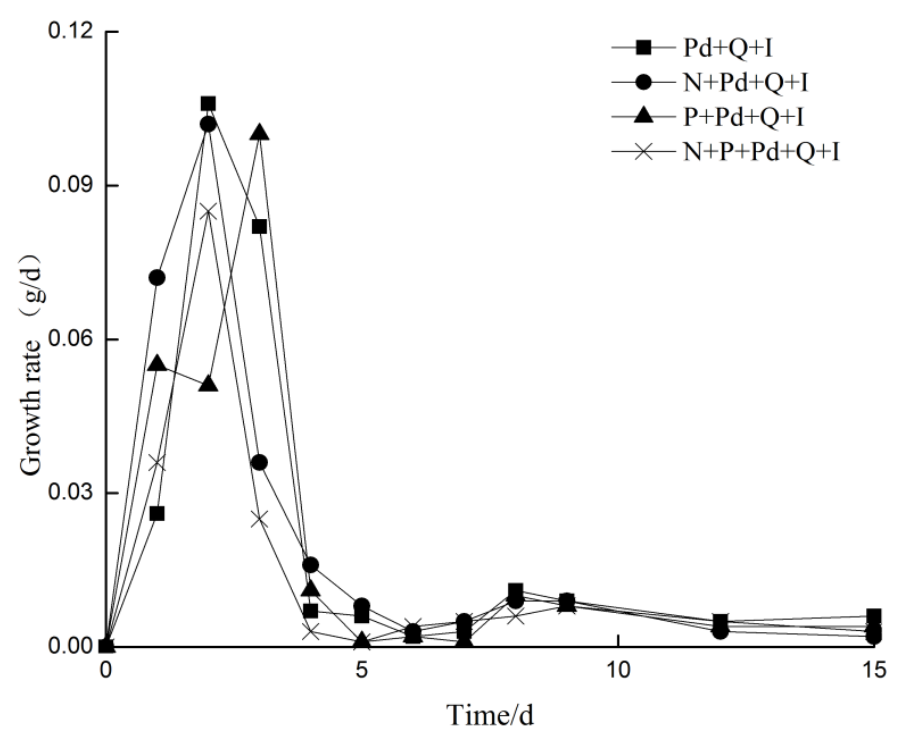

Figure 8. Growth rate of white-rot fungi biomass. 
Figure 9 illustrates that the $\mathrm{pH}$ of the four systems in the first four days also changed similarly and then again reached the lowest values on the $4-5^{\text {th }}$ day. This drop in $\mathrm{pH}$ can be attributed to the degradation of phenol and indole and their intermediates. However, other aromatic acid based compounds present (the degradation products of the cellulosic components of culture media) also play an important role. It was observed that the $\mathrm{pH}$ of $\mathrm{N}+\mathrm{Pd}+\mathrm{Q}+\mathrm{I}$ and $\mathrm{N}+\mathrm{P}+\mathrm{Pd}+\mathrm{Q}+\mathrm{I}$ systems after four days was comparatively higher than that of the other two. This may be caused due to the presence of a stable buffer system formed between ammonia nitrogen and aromatic acids after the concentration of ammonia nitrogen was stable, and showed weak alkalinity.

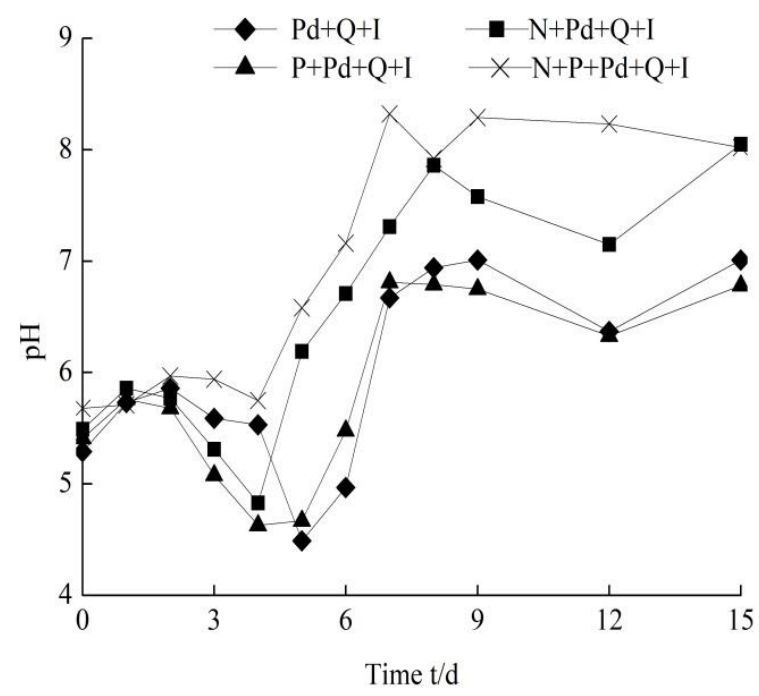

Figure 9. Time dependent changes in the $\mathrm{pH}$ of the four systems.

\section{Treatment of Actual Coking Wastewater by White-Rot Fungi}

The degradation of actual coking wastewater was mainly dependent upon the role of divalent metal ions in the degradation of nitrogen heterocyclic compounds. In addition, other factors that influenced the process of degradation included the concentration of other major pollutants in coking wastewater and the biological characteristics of white-rot fungi in the four degradation systems (no metal ions (CK) / 
$\mathrm{Mg}$ (II) / Cu (II) / Mn (II)). The reason behind the selection of $\mathrm{Cu}$ (II), $\mathrm{Mn}$ (II) and $\mathrm{Mg}$ (II) in the present study was the fact that these divalent ions exist in the actual coking wastewater and it was intended to elucidate the effects that their changing concentration may imply on the biological properties of white rot fungi and hence on the rate of degradation of the wastewater. Since COD of the substrate in the culture medium was known to be very high, which in turn had a profound influence on the determination of the COD of the system; it was not considered for analysis in the experiment.

\section{Effect of Divalent Metal Ion on the Removal of Nitrogen Heterocyclic Compounds}

According to the Figure 10, white-rot fungi were cultured for 15 days on solid medium, and the removal rates of quinoline in the four degradation systems were $65 \%, 76 \%, 65 \%$ and $78 \%$, respectively. It was found that the addition of $\mathrm{Mg}$ (II) and $\mathrm{Mn}$ (II) promoted the degradation of quinoline by white-rot fungi and even improved (slightly) the removal rate of quinoline. On the other hand, $\mathrm{Cu}$ (II) was not found to have any significant effects on the degradation of quinoline by white-rot fungi. It could be seen from Figure 11 that the removal rate of indole in the system of $\mathrm{Mg}$ (II), $\mathrm{Cu}$ (II) and $\mathrm{Mn}$ (II) could reach more than $99 \%$, while Figure 12 illustrates that the removal rates of pyridine in the four systems were $38 \%, 32 \%, 24 \%$ and $31 \%$, respectively. It was also found that the divalent metal ions inhibited the degradation of pyridine, out of which the inhibition effect of $\mathrm{Cu}$ (II) was the most obvious. 


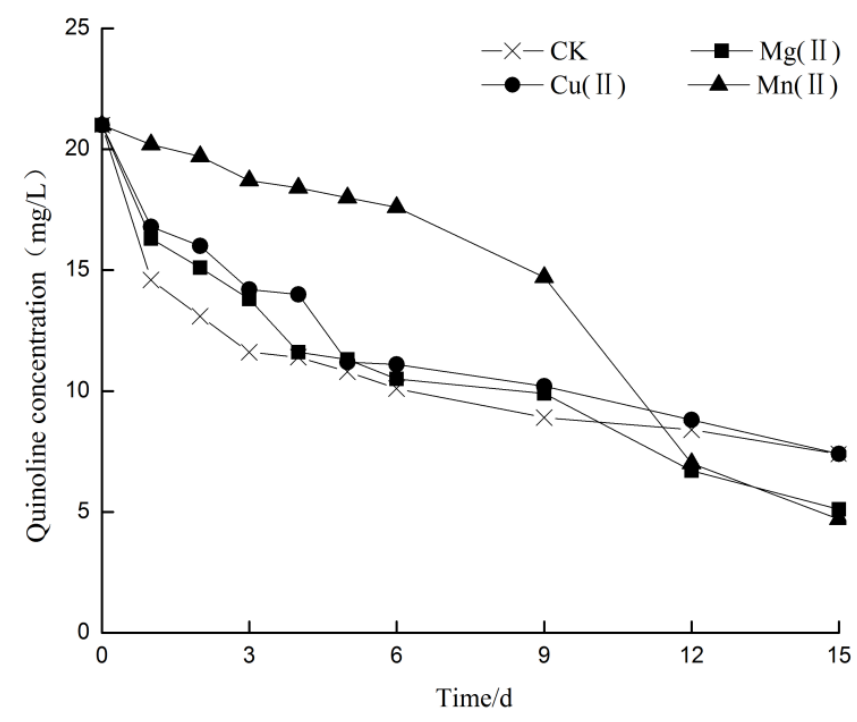

Figure 10. Time dependent changes in quinoline concentration.

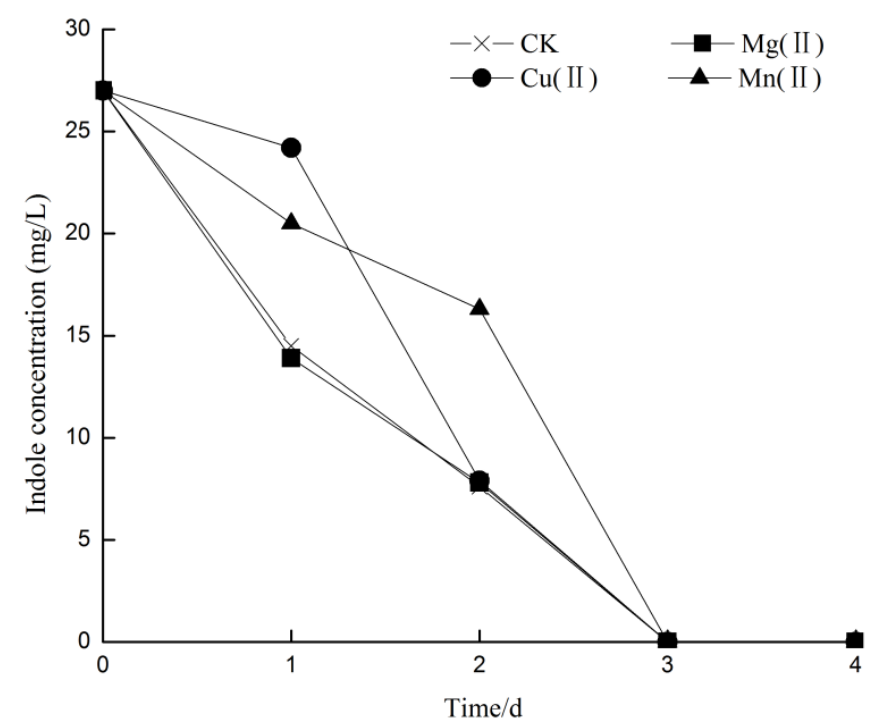

Figure 11. Time dependent changes of indole concentration. 


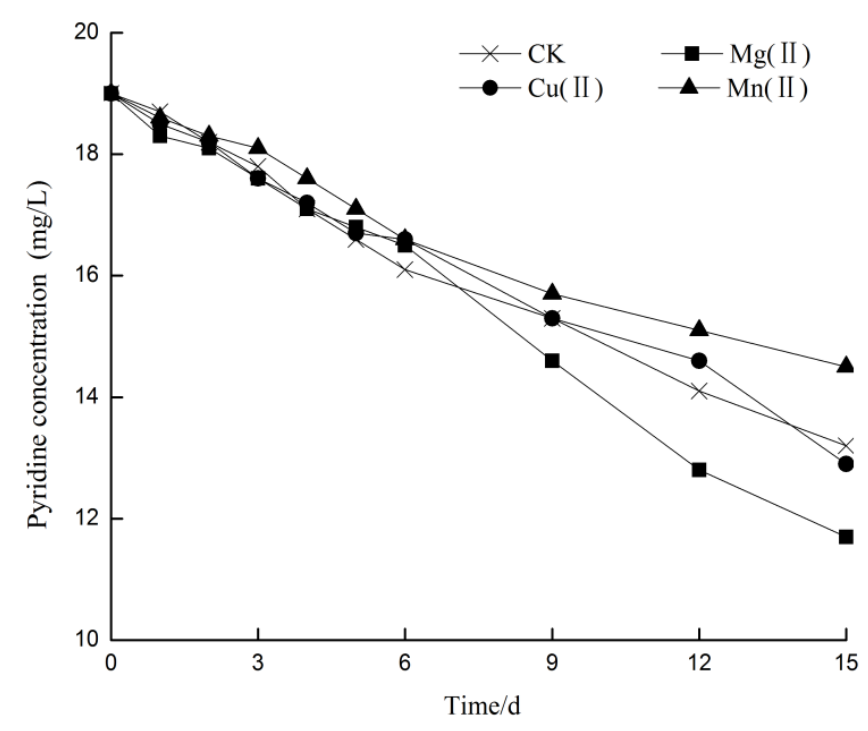

Figure 12. Time dependent changes of pyridine concentration.

It could be seen from Figure 13 and Figure 14 that the change in ammonia nitrogen concentration also followed a similar trend. The fluctuation range during the $0-6^{\text {th }}$ days was very less and further decreased during the $6-12^{\text {th }}$ days. An increase in fluctuation was observed during the $12-15^{\text {th }}$ days. The changes in ammonia nitrogen concentration were also found to be similar to that of the simulated wastewater, both of which go through the process of declining first followed by a systematic rise in the values. Due to the high concentration of indole and phenol in the simulated wastewater, the overall change in ammonia nitrogen concentration was mainly brought about due to degradation of indole and phenol. In the actual coking wastewater, the change of ammonia concentration is mainly related to the removal of phenol (phenol concentration is $323 \mathrm{mg} / \mathrm{L}$, and indole concentration is small in the actual coking wastewater). Figure 13 clearly demonstrates that phenol was removed significantly on the $6^{\text {th }}$ day after which the ammonia concentration began to decrease. White-rot fungi were found to remove more than $99 \%$ of the phenol content in four of these systems. However, the initial degradation of phenol was slow, especially due to the inhibition of laccase secretion of white-rot fungi in the early stages, as the fungi were in its domestication stage. After five days, the fungi adapted to the actual coking wastewater environment, which led to an increase in the laccase enzymatic activity levels that further resulted in the rapid degradation of phenol. 


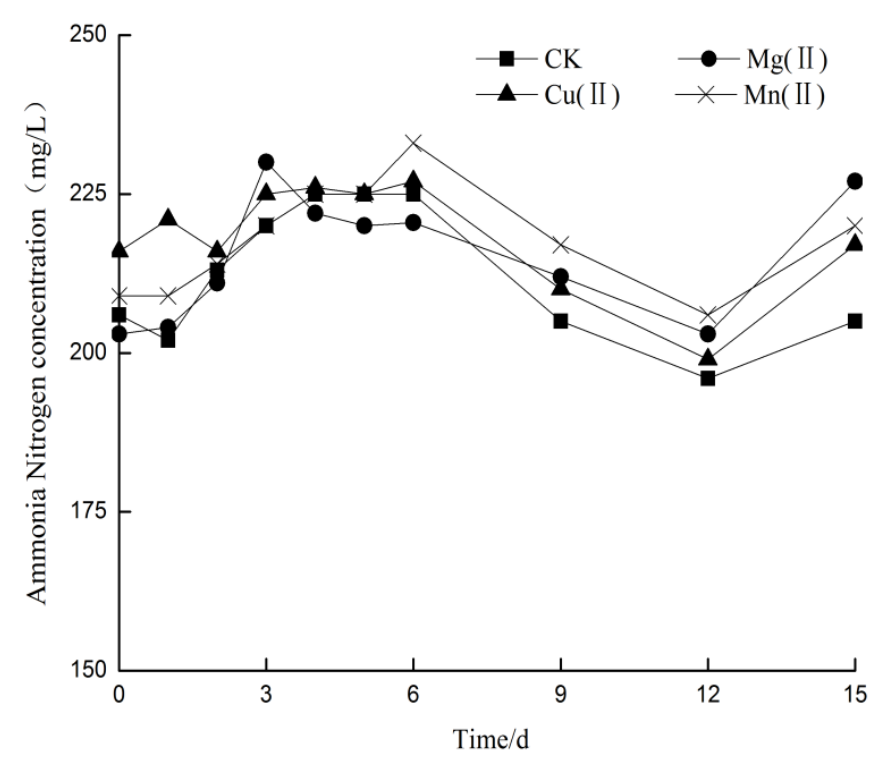

Figure 13. Time dependent changes of ammonia nitrogen concentration.

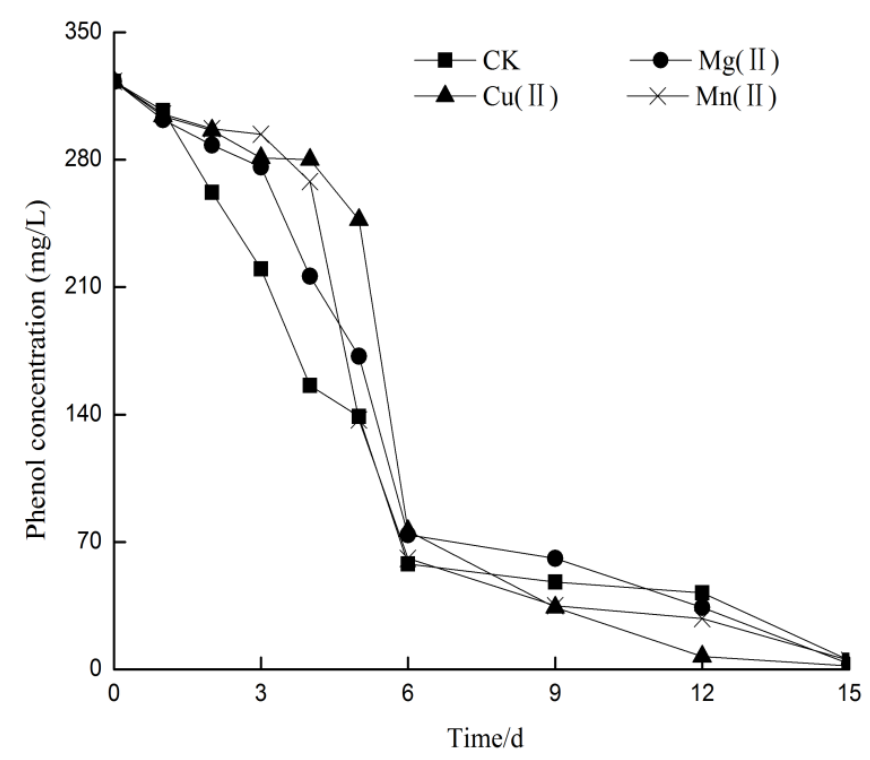

Figure 14. Time dependent changes of phenol concentration.

\section{Change in Biomass and Enzyme Activity Levels of White-Rot Fungi}


It can be seen from Figure 15, that on the first five days, the laccase secretion of white-rot fungi was inhibited. The laccase activity levels were maintained at about $10 \mathrm{U} / \mathrm{mL}$, which is due to the simultaneous presence of a variety of other toxic and harmful substances in coking wastewater that may play significant roles in inhibition of enzyme secretion in white rot fungi (Asif et al., 2017). After five days of domestication, the white-rot fungi supposedly adapted to the actual coking wastewater culture environment which subsequently led to an increase in the enzyme activity levels. Results obtained from the present experiment demonstrated that the laccase secretion of white-rot fungi in the CK system was similar to $\mathrm{Mg}$ (II) system and $\mathrm{Mn}$ (II) system. This indicated that the addition of $1.0 \mathrm{mM} / \mathrm{L} \mathrm{of} \mathrm{Mg}$ (II) and $\mathrm{Mn}$ (II) had no significant effects on the laccase secretion activities of the fungi. Furthermore, the enzymatic activity of the white-rot fungi in the $\mathrm{Cu}$ (II) system was the same as that of the other three systems, especially in the first five days. On the $6-12^{\text {th }}$ day, the activity of laccase was found to increase slowly and the laccase secretion was still inhibited. On the $12-15^{\text {th }}$ day, the activity of laccase was found to increase rapidly and reached the level of $412 \mathrm{U} / \mathrm{mL}$ on the 15 th day. It was thus concluded that the presence of $1.0 \mathrm{mM} / \mathrm{L} \mathrm{Cu}$ (II) could promote laccase secretion.

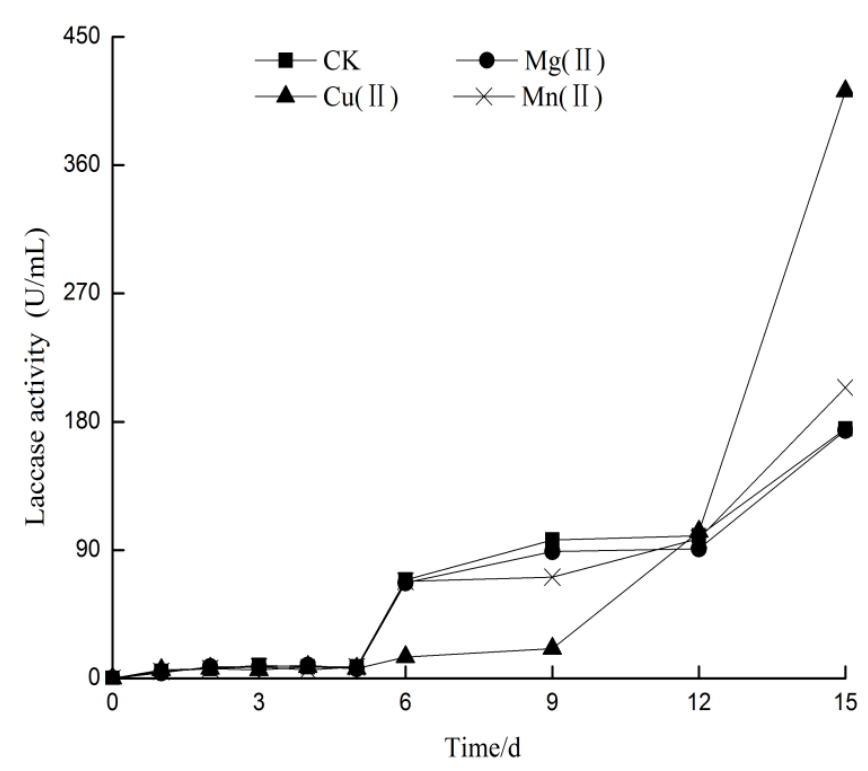

Figure 15. Time dependent changes of laccase activity of white-rot fungi. 
As is shown in Figure 16, the growth rate of white-rot fungi biomass in $\mathrm{CK}, \mathrm{Mg}$ (II), Cu (II) and $\mathrm{Mn}$ (II) in the actual coking wastewater reached a maximum of $0.0166,0.0238,0.0111$ and $0.0373 \mathrm{~g} / \mathrm{d}$ on $2^{\text {nd }}, 1^{\text {st }}, 1^{\text {st }}$ and $1^{\text {st }}$ day, respectively. It was thus concluded that the presence of 1.0 $\mathrm{mM} / \mathrm{L} \mathrm{Mg} \mathrm{(II)} \mathrm{and} \mathrm{Mn} \mathrm{(II)} \mathrm{could} \mathrm{promote} \mathrm{the} \mathrm{growth} \mathrm{of} \mathrm{white-rot} \mathrm{fungi,}$ due to which the fungi maintained a high biomass growth rate. In contrast to the influence on the laccase secretion of white-rot fungi, 1.0 $\mathrm{mM} / \mathrm{L} \mathrm{Cu}$ (II) inhibited the development of white-rot fungi strains, and the growth rate of white-rot fungi biomass was low during the whole experiment. The two peaks of biomass growth rate that were observed during the experiment corresponded to the $1^{\text {st }}$ day and the $6^{\text {th }}$ day in the degradation system.

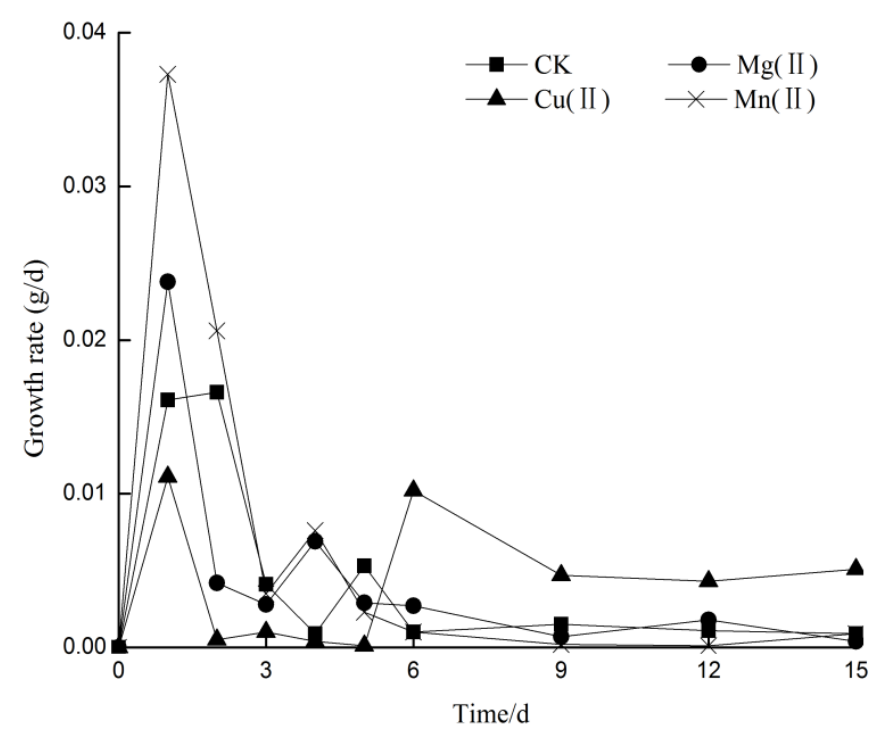

Figure 16. Time dependent changes in the growth rate of white-rot fungi biomass.

As that the straw filter medium was diluted twice caused the reduction of nutrient, while the actual coking wastewater composition is complex and toxic, in the actual coking wastewater culture environment, the growth rate of white-rot fungi biomass was found to be much lower than the simulated wastewater.

\section{Discussion}


In the simulated wastewater, the addition of ammonia nitrogen and phenol affected the enzyme secretion and enzyme activity of white-rot fungi, especially in the $P d+Q+I$ degradation system. The addition of ammonia nitrogen provided a nitrogen-rich culture environment to the white-rot fungi, and the phenol structure (with phenolic hydroxyl) induced the laccase secretion of the white-rot fungi. It was also found that quinoline could be better degraded in neutral or acidic environments while the degradation rate declined rapidly in an alkaline environment (Thomsen et al., 1998). The addition of ammonia nitrogen increased the $\mathrm{pH}$ of the system and thus inhibited the degradation rate of quinoline. However, the addition of phenol reduced the $\mathrm{pH}$ of the system to promote the degradation of quinoline. It was observed that $\mathrm{OH}$ plays a significant role in quinoline degradation due to the fact that phenolic hydroxyl groups on phenol are less stable (Camarero et al., 2010). They can thus attack the aromatic compounds, produce positive carbon ions and then induce a series of reactions that promotes the degradation of quinoline. On the other hand, the alcoholic hydroxyl groups on the ammonia nitrogen (ammonium tartrate) are relatively stable and have little effect on the degradation of quinoline.

In the actual coking wastewater, presence of moderate concentrations of $\mathrm{Mg}$ (II) and $\mathrm{Mn}$ (II) could promote the growth of white-rot fungi, so that more laccase was secreted and the removal rate of quinoline was slightly improved (Baldrian, 2003). The rate of initiation of the laccase secretion of white-rot fungi in the actual coking wastewater environment was much slower than simulated wastewater. Laccase activity was maintained at a low level on 0-12 days, but this is not due to the fact that some metal ions in the solution causes fungi in oxidative stress (Galhaup et al., 2001). The lower enzyme activity is mainly due to the complex composition of the actual coking wastewater. Such wastewater contains a lot of toxic and harmful substances which inhibit secretion of laccase (Asif et al., 2017). On 12-15 th day, the laccase activity in the actual coking wastewater of $\mathrm{Cu}$ (II) system was twice as much as the laccase activity in other systems. It has already been established that the activity center of white-rot fungi laccase constitutes of four $\mathrm{Cu}$ ions constitute (Strong et al., 2011; Baldrian et al., 2006; Giardina et al., 2010). White-rot fungi allow direct passage of $\mathrm{Cu}$ (II) through its cell walls. Hence, the presence of $\mathrm{Cu}$ ions, even in concentrations of less than $1 \mathrm{mM} / \mathrm{L}$ can also act as an inducer and promote laccase secretion. Meanwhile, the presence of a variety of other aromatic and phenolic compounds induced continued maintenance of an activated state of the white-rot fungi which further promoted its laccase secretion activities (Tychanowicz et al., 2006). Cu 
(II) can also directly activate the active site of extracellular laccase enzymes to improve its activity.

\section{Conclusion}

In simulated wastewater, ammonia nitrogen had an inhibitory effect on quinoline degradation, while the promoting effects of phenol on the same were even greater than the inhibition effect of ammonia nitrogen. White-rot fungi could remove more than $99 \%$ of indole only after three days. On the other hand, ammonia nitrogen and phenol had little effect on the degradation of indole, but they were beneficial for the degradation of pyridine and improving the peak of laccase activity. In actual coking wastewater, $\mathrm{Mg}$ (II) and $\mathrm{Mn}$ (II) promoted the degradation of quinoline and slightly improved the removal rate of quinoline. However, $\mathrm{Cu}$ (II) had no effect on the degradation of quinoline. It was concluded that the divalent metal ions had no significant effects on the degradation of indole, but they had a profound impact on the inhibition of the degradation of pyridine. Among all the metals studies, and the inhibition effect of $\mathrm{Cu}$ (II) was the most obvious. It is also important to note that though the addition of $1.0 \mathrm{mM} / \mathrm{L} \mathrm{Mg}$ (II) and $\mathrm{Mn}$ (II) had no significant effects on the secretion of laccase, they could still promote the growth of white-rot fungi so that the fungi maintained high biomass growth rate. Conversely, $1.0 \mathrm{mM} / \mathrm{L} \mathrm{Cu}$ (II) could promote the secretion of laccase, but inhibited the development of white-rot fungi.

\section{Acknowledgments}

This work was supported By the National Natural Science Foundation of China (Grant No 41571306) and State Key Laboratory of Biogeology and Environmental Geology (Grant No GBL21507).

\section{Reference}

Joshi, D. R., Zhang, Y., Tian, Z., Gao, Y. \& Yang, M. (2015). Performance and microbial community composition in a long-term sequential anaerobic-aerobic bioreactor operation treating coking wastewater. Applied Microbiology \& Biotechnology,100 (18), 1-12. doi: 10.1007/s00253-016-7591-8.

Eisentraeger, A., Brinkmann, C., Hollert, H., Sagner, A., Tiehm, A. \& 
Neuwoehner, J. (2010). Heterocyclic compounds: toxic effects using algae, daphnids, and the salmonella/microsome test taking methodical quantitative aspects into account. Environmental Toxicology \& Chemistry, 27(7), 1590-1596, doi: 10.1897/07-201.1.

Rasool, K., Mahmoud, K. A. \& Lee, D. S. (2015). Influence of co-substrate on textile wastewater treatment and microbial community changes in the anaerobic biological sulfate reduction process. journal of Hazardous Materials, 299, 453-461, doi: 10.1016/j.jhazmat.2015.07.044.

Martinez, I., Santos, V. E., Alcon, A. \& Garcia-Ochoa, F. (2015). Enhancement of the biodesulfurization capacity of Pseudomonas putida CECT5279 by co-substrate addition. Process Biochemistry, 50(1), 119-124, doi: 10.1016/j.procbio.2014.11.001.

Wen, J., Gao, D., Zhang, B. \& Liang, H. (2011). Co-metabolic degradation of pyrene by indigenous white-rot fungus Pseudotrametes gibbosa from the northeast china. International Biodeterioration \& Biodegradation, 65(4), 600-604, doi: 10.1016/j.ibiod.2011.03.003.

Chen, Y., Xie, X. G., Ren, C. G. \& Dai, C. C. (2013). Degradation of n-heterocyclic indole by a novel endophytic fungus Phomopsis liquidambari. Bioresource Technology, 129(129C), 568-574, doi: 10.1016/j.biortech.2012.11.100.

Wang, C., Zhang, M., Cheng, F. \& Geng, Q. (2015). Biodegradation characterization and immobilized strains' potential for quinoline degradation by Brevundimonas sp. K4 isolated from activated sludge of coking wastewater. Bioscience Biotechnology \& Biochemistry, 79(1), 164-170, doi: 10.1080/09168451.2014.952615.

Bai, Y., Sun, Q., Cui, Z., Wen, D. \& Tang, X. (2009). Aerobic degradation of pyridine by a new bacterial strain, Shinella zoogloeoides, BC026. Journal of Industrial Microbiology \& Biotechnology, 36(11), 1391-1400, doi: $10.1007 /$ s10295-009-0625-9.

Pointing, S. (2001). Feasibility of bioremediation by white-rot fungi. Applied Microbiology \& Biotechnology, 57(1-2), 20, doi: $10.1007 / \mathrm{s} 002530100745$.

Ren, D., Zhou, S., Li, Q., Wang, C., Zhang, S. \& Zhang, H. (2012). Enhanced electrokinetic remediation of quinoline-contaminated soils. Toxicological \& Environmental Chemistry Reviews, 98(5-6), 585-600, doi: 10.1080/02772248.2015.1133383.

Stella, T., Covino, S., Čvančarová M, Filipová, A., Petruccioli, M. \& D'Annibale, A., et al. (2016). Bioremediation of long-term pcb-contaminated soil by white-rot fungi. Journal of Hazardous Materials, 324, doi: 10.1016/j.jhazmat.2016.11.044.

Bourbonnais, R. \& Paice, M. G. (1992). Demethylation and 
delignification of kraft pulp by Trametes versicolor, laccase in the presence of 2,2'-azinobis-(3-ethylbenzthiazoline-6-sulphonate). Applied Microbiology \& Biotechnology, 36(6), 823-827, doi: 10.1007/BF00172202.

Asif, M. B., Hai, F. I., Hou, J., Price, W. E. \& Nghiem, L. D. (2017). Impact of wastewater derived dissolved interfering compounds on growth, enzymatic activity and trace organic contaminant removal of white rot fungi - a critical review. Journal of Environmental Management, 201, 89, doi: 10.1016/j.jenvman.2017.06.014.

Thomsen, A. B. (1998). Degradation of quinoline by wet oxidation kinetic aspects and reaction mechanisms. Water Research, 32(1), 136-146, doi: 10.1016/S0043-1354(97)00200-5.

Cañas, A. I. \& Camarero, S. (2010). Laccases and their natural mediators: biotechnological tools for sustainable eco-friendly processes. Biotechnology Advances, 28(6), 694-705, doi: 10.1016/j.biotechadv.2010.05.002.

Baldrian, P. (2003). Interactions of heavy metals with white-rot fungi. Enzyme \& Microbial Technology, 32(1), 78-91, doi: 10.1016/S0141-0229(02)00245-4.

Galhaup, C. \& Haltrich, D. (2001). Enhanced formation of laccase activity by the white-rot fungus Trametes pubescens in the presence of copper. Applied Microbiology \& Biotechnology, 56(1-2), 225, doi: $10.1007 / \mathrm{s} 002530100636$.

Strong, P. J. \& Claus, H. (2011). Laccase: a review of its past and its future in bioremediation. Critical Reviews in Environmental Science \& Technology, 41(4), 373-434, doi: 10.1080/10643380902945706.

Baldrian, P. (2006). Fungal laccases - occurrence and properties. Fems Microbiology Reviews, 30(2), 215-242, doi: 10.1111/j.1574-4976.2005.00010.x.

Giardina, P., Faraco, V., Pezzella, C., Piscitelli, A., Vanhulle, S. \& Sannia, G. (2010). Laccases: a never-ending story. Cellular \& Molecular Life Sciences Cm/s, 67(3), 369-385, doi: 10.1007/s00018-009-0169-1.

Tychanowicz, G. K., Souza, D. F. D., Souza, C. G. M., Kadowaki, M. K. \& Peralta, R. M. (2006). Copper improves the production of laccase by the white-rot fungus Pleurotus pulmonarius in solid state fermentation. Brazilian Archives of Biology \& Technology, 49(5), 699-704, doi: 10.1590/S1516-89132006000600002. 